\title{
Hubungan Dukungan Sosial Keluarga dengan Perilaku Perawatan Diri pada Klien Diabetes Melitus Tipe 2 di Wilayah Kerja Puskesmas Kaliwates, Jember
}

\author{
(Correlation between Family Social Support and Self Care \\ Behaviour in Client with Type 2 Diabetes Mellitus in \\ the area of Kaliwates Public Health Center, Jember)
}

\author{
Wahyuningtias Rahmadani, Hanny Rasni, Kholid Rosyidi Muhammad Nur \\ Fakultas Keperawatan Universitas Jember \\ Jl. Kalimantan No.37 Kampus Tegal Boto Jember. Telp./Fax. (0331) 323450 \\ e-mail: hannyrasni@yahoo.co.id
}

\begin{abstract}
Type 2 diabetes mellitus (T2DM) is a metabolic disease that can cause various chronic complications and they can be minimized by self-care. One of the factors that affect self-care in diabetic clients is family social support. The aim of the research was to analyze the correlation between family social support and self care behavior client with T2DM)in the area of Kaliwates public health center, Jember. This research applied an observational analytic design with cross-sectional approach. A total of 84 respondents were enrolled in this study by using purposive sampling technique. The data collection method used the HDFSS (Hensarling Diabetes Family Support Scale) and SDSCA (Summary of Diabetes Self Care Activity) questionnaires, it conducted on January $7^{\text {th }}-22^{\text {nd }}$ 2019. The data analysis used Spearman correlation test with a significance level of 0.05. The result showed that median of the family social support was 86 with a minimum value of 69 and a maximum value of 106, whereas the mean value of self-care behaviour was 2,27 days with a standard deviation of 0.45 days. There was a significant positive correlation between family sosial support and selfcare behaviour ( $p$ value: $0.001 ; r ;+0.378$ ), meaning that the higher the level of family social support the better the self-care behaviour. This study suggests the importance of assessing family social support to improve self-care in clients with type 2 diabetes mellitus.
\end{abstract}

Keywords: family social support, self-care behavior, type 2 diabetes mellitus

\begin{abstract}
Abstrak
Diabetes Melitus tipe 2 (DMT2) merupakan penyakit metabolik yang dapat menimbulkan berbagai komplikasi kronik, dan dapat diminimalisir dengan perawatan diri. Salah satu faktor yang dapat mempengaruhi perawatan diri pada klien diabetes adalah dukungan sosial keluarga. Tujuan penelitian untuk menganalisis hubungan antara dukungan sosial keluarga dengan perilaku perawatan diri klien DM tipe 2 di Wilayah Kerja Puskesmas Kaliwates, Jember. Penelitian ini menggunakan desain observasional analitik dengan pendekatan cross sectional. Sebanyak 84 responden dipilih menggunakan teknik purposive sampling. Pengumpulan data menggunakan kuesioner HDFSS (Hensarling Diabetes Family Support Scale) dan SDSCA (Summary of Diabetes Self Care Activity) yang dilaksanakan pada tanggal 7 - 22 Januari 2019. Analisis data menggunakan uji korelasi spearmen dengan tingkat signifikasi 0,05 . Hasil penelitian menunjukkan bahwa nilai median dukungan sosial keluarga adalah 86 dengan nilai minimal 69 dan nilai maksimal 106 sedangkan nilai rata - rata perilaku perawatan diri adalah 2,27 $\pm 0,45$ hari. Terdapat hubungan signifikan yang bersifat positif antara dukungan sosial keluarga dan perilaku perawatan diri ( $p$ value: 0,$001 ; r$ : $+0,378$ ). Hal ini berarti semakin tinggi nilai dukungan sosial keluarga maka semakin baik perilaku perawatan diri. Hasil penelitian ini menunjukkan bahwa pentingnya mengkaji dukungan sosial keluarga untuk meningkatkan perilaku perawatan diri klien DM tipe 2.
\end{abstract}

Kata Kunci : Dukungan Sosial Keluarga, Perilaku perawatan diri, Diabetes melitus tipe 2 


\section{Pendahuluan}

Diabetes Melitus (DM) merupakan suatu permasalahan kesehatan yang penting, karena masuk dalam empat prioritas penyakit tidak menular dan sebagai penyebab utama kecacatan hingga kematian [1]. Data kejadian DM menunjukkan sebanyak 425 juta orang dewasa mengidap DM dan jumlahnya diperkirakan akan meningkat sebesar $48 \%$ menjadi 629 juta orang pada tahun 2045 [2].

Prevalensi di dunia yang berkaitan dengan DM pada tahun 2017, Indonesia menduduki peringkat ke 6 setelah negara Cina, India, USA, Brazil, dan Mexico dengan jumlah 10,3 juta jiwa yang terdiagnosa diabetes, kejadian ini diperkirakan mengalami peningkatan dengan jumlah 16,7 juta jiwa pada tahun 2045 [3]. Provinsi jawa timur menduduki peringkat kelima dengan jumlah penderita DM sebanyak 2,1\% [4].

Prevalensi DM tahun 2013 di Kabupaten Jember menduduki peringkat ketiga pengidap tertinggi sebesar $17,49 \%$ setelah penyakit Infeksi Saluran Pernafasan Akut (ISPA) dan Hipertensi [5]. Berdasarkan data yang diperoleh dari Puskesmas Kaliwates tahun 2018 dari bulan Januari sampai dengan bulan Juli jumlah kunjungan klien DM tipe 2 sebanyak 159 orang.

DM dikenal sebagai "lifelong disease" atau penyakit yang tidak dapat disembuhkan selama rentang hidup kliennya sehingga dapat mempengaruhi seluruh aspek kehidupan. Salah satu dari dampak yang muncul adalah meningkatnya potensi resiko komplikasi yang dapat mengakibatkan kematian [6].

Diabetes merupakan penyebab utama penyakit jantung, gagal ginjal, amputasi ekstremitas bawah dan kebutaan [7]. Masalah masalah terkait penyakit yang diderita oleh klien DM dapat diminimalisir saat penderita DM mempunyai kemampuan dan pengetahuan yang baik untuk mengontrol penyakitnya, yaitu dengan perawatan diri [8].

Faktor yang mempengaruhi perawatan diri pada klien DM salah satunya adalah dukungan sosial keluarga [9]. Perencanaan pengelolaan diabetes harus dibicarakan secara terapeutik antara keluarga dan klien, sehingga keluarga menyadari pentingnya keikutsertaan dalam perawatan pasien diabetes [10].

Dukungan sosial keluarga dapat meningkatkan kemampuan penyandang DM tipe 2 untuk melakukan aktivitas perawatan diri [11]. Adanya dukungan sosial keluarga dapat menimbulkan perasaan nyaman dan aman, menumbuhkan rasa perhatian terhadap diri sendiri, serta meningkatkan motivasi dalam menjalani pengobatan dan perawatan diri sehingga mencegah munculnya stress terhadap klien DM $[12,13]$. Tujuan penelitian ini adalah menganalisa hubungan dukungan sosial keluarga dengan perilaku perawatan diri pada klien diabetes melitus tipe 2 di wilayah kerja Puskesmas Kaliwates Kabupaten Jember.

\section{Metode Penelitian}

Desain penelitian ini adalah observasional analitik dengan pendekatan cross sectional. Teknik pengambilan sampel menggunakan non probability sampling dengan purposive sampling yang sebelumnya dilakukan skrining MMSE (Mini Mental State Examination) serta kriteria inklusi dan eklusi. Jumlah sampel sebanyak 84 orang.

Kuesioner dalam penelitian ini menggunakan Hensarling Diabetes Family Support Scale (HDFSS) dan Summary of Diabetes Self-Care Activity (SDSCA). Pengambilan data dilakukan secara door to door dan dilaksanakan selama 2 minggu lebih 2 hari di wilayah kerja Puskesmas Kaliwates Kabupaten Jember yang meliputi Kelurahan Tegal Besar, Kelurahan Kaliwates, dan Kelurahan Kebonagung. Teknik analisa data menggunakan uji statistik spearman dengan signifikan 0,05.

\section{Hasil}

\section{Karakteristik Responden}

Tabel 1. Distribusi Responden Menurut Usia pada Klien DM Tipe 2 di Wilayah Kerja Puskesmas Kaliwates Kabupaten Jember (Januari, 2019; $\mathrm{n}=84$ )

\begin{tabular}{ccc}
\hline Variabel & Mean & SD \\
\hline Usia (tahun) & 57,64 & 8,83 \\
\hline
\end{tabular}

Tabel 1 menjelaskan distribusi klien DM Tipe 2 berdasarkan usia. rata-rata usia responden adalah 57,64 tahun dengan standar deviasi yakni 8.83 tahun.

Tabel 2. Distribusi Responden Menurut Lama Terdiagnosa DM pada Klien DM Tipe 2 di Wilayah Kerja Puskesmas Kaliwates Kabupaten Jember (Januari, 2019; n=84)

\begin{tabular}{cccc}
\hline Variabel & Mean & Median & Min - Maks \\
\hline $\begin{array}{c}\text { Lama DM } \\
\text { (tahun) }\end{array}$ & 6 & 5 & $0,25-15$ \\
\hline
\end{tabular}

Tabel 2 menjelaskan distribusi klien DM tipe 2 menurut lama terdiagnosa DM didapatkan nilai median yaitu 5 tahun, dengan nilai minimal 0,25 tahun dan maksimal 15 tahun. 
Tabel 3. Distribusi Responden berdasarkan Jenis Kelamin, Tingkat Pendidikan, dan Pekerjaan pada Klien DM tipe 2 di Wilayah Kerja Puskesmas Kaliwates Kabupaten Jember (Januari, 2019; $n=84$ ).

\begin{tabular}{|c|c|c|c|}
\hline & Variabel & Jumlah & $\%$ \\
\hline \multicolumn{4}{|c|}{ 1.Jenis Kelamin } \\
\hline a. & Laki-Laki & 34 & 40,5 \\
\hline b. & Perempuan & 50 & 59,5 \\
\hline Total & & 84 & 100 \\
\hline \multicolumn{4}{|c|}{ 2.Pendidikan Terakhir } \\
\hline a. & Tidak Sekolah & 23 & 27,4 \\
\hline b. & SD & 13 & 15,5 \\
\hline c. & SMP & 15 & 17,9 \\
\hline d. & SMA & 29 & 34,5 \\
\hline e. & PT & 4 & 4,8 \\
\hline Total & & 84 & 100 \\
\hline \multicolumn{4}{|c|}{ 3.Pekerjaan } \\
\hline a. & Tidak Bekerja & 20 & 23,8 \\
\hline b. & $\begin{array}{ll}\text { lbu } & \text { Rumah } \\
\text { Tangga } & \end{array}$ & 26 & 31,0 \\
\hline c. & Wiraswasta & 17 & 20,2 \\
\hline d. & PNS/ Pensiunan & 8 & 9,5 \\
\hline e. & Pedagang & 6 & 7,1 \\
\hline & $\begin{array}{l}\text { Karyawan } \\
\text { Swasta }\end{array}$ & 6 & 7,1 \\
\hline g. & Tukang Becak & 1 & 1,2 \\
\hline Total & & 84 & 100 \\
\hline
\end{tabular}

Tabel 3 diketahui bahwa distribusi klien DM tipe 2 dari 84 responden berdasarkan jenis kelamin didapatkan jenis kelamin perempuan lebih banyak sebanyak 50 orang $(59,5 \%)$ dibandingkan dengan jenis kelamin laki-laki yaitu sebanyak 34 orang $(40,5 \%)$. Jika dilihat dari tingkat pendidikan terakhir klien DM tipe 2 paling banyak adalah SMA dengan jumlah 29 orang $(34,5 \%)$ sedangkan paling sedikit adalah Perguruan Tinggi sebanyak 4 orang $(4,8 \%)$. Dilihat dari jenis pekerjaan responden juga diketahui paling banyak yaitu ibu rumah tangga dengan jumlah 26 orang $(31,0 \%)$.

\section{Dukungan Sosial Keluarga}

Tabel 4. Nilai Rerata Dukungan Sosial Keluarga pada Klien DM Tipe 2 di Wilayah Kerja Puskesmas Kaliwates Kabupaten Jember ( Januari, 2019; $\mathrm{n}=84$ )

\begin{tabular}{cccc}
\hline Variabel & Mean & Median & Min-Maks \\
\hline $\begin{array}{c}\text { Dukungan } \\
\text { Sosial } \\
\text { Keluarga }\end{array}$ & 85,70 & 86 & $69-106$ \\
\hline
\end{tabular}

Hasil yang didapatkan dari abel 4 menunjukkan bahwa nilai median dukungan sosial keluarga 86 sedangkan untuk nilai minimal e-Journal Pustaka Kesehatan, vol. 7 (no. 2), Mei 2019 dukungan sosial keluarga adalah 69 dan nilai maksimal yaitu 106 .

Tabel 5. Nilai Rerata Indikator Dukungan Sosial Keluarga pada Klien DM tipe 2 di Wilayah Kerja Puskesmas Kaliwates Kabupaten Jember (Januari, 2019; n=84)

\begin{tabular}{cccc}
\hline Indikator & Mean & Median & Min-Maks \\
\hline $\begin{array}{c}\text { Dukungan } \\
\text { Emosional }\end{array}$ & 3,20 & 3,20 & $2,60-3,90$ \\
\hline $\begin{array}{c}\text { Dukungan } \\
\text { Penghargaan }\end{array}$ & 2,62 & 2,62 & $2,25-3,38$ \\
\hline $\begin{array}{c}\text { Dukungan } \\
\text { Instrumental }\end{array}$ & 3,13 & 3,12 & $2,38-3,88$ \\
\hline $\begin{array}{c}\text { Dukungan } \\
\text { Informasi }\end{array}$ & 2,53 & 2,66 & $1,67-4,00$ \\
\hline
\end{tabular}

Hasil yang didapatkan dari tabel 5, menunjukkan bahwa nilai rata - rata yang tertinggi dari indikator dukungan sosial keluarga yaitu dukungan emosional dengan nilai rata - rata 3,20 selanjutnya nilai rata - rata terendah yaitu dukungan informasi dengan nilai 2,53.

Tabel 6. Distribusi Responden berdasarkan kategori Dukungan Sosial Keluarga pada Klien DM Tipe 2 di Wilayah Kerja Puskesmas Kaliwates Kabupaten Jember $(\mathrm{N}=84)$

\begin{tabular}{l|c|c}
\hline \multicolumn{1}{c|}{ Variabel } & Jumlah & $\%$ \\
\hline $\begin{array}{l}\text { Dukungan Sosial Keluarga } \\
\text { Baik }\end{array}$ & 82 & $97,6 \%$ \\
\hline $\begin{array}{l}\text { Dukungan Sosial Keluarga } \\
\text { Buruk }\end{array}$ & 2 & $2,4 \%$ \\
\hline
\end{tabular}

Tabel 6 menunjukkan bahwa variabel dukungan sosial keluarga terhadap responden yang paling banyak yaitu dalam kategori baik sebanyak 82 orang $(97,6 \%)$ dan untuk responden yang memiliki dukungan sosial keluarga buruk kepada klien DM tipe 2 sebanyak 2 orang (2,4\%).

\section{Perilaku Perawatan Diri}

Tabel 7. Nilai Rerata Perilaku Perawatan Diri pada Klien DM Tipe 2 di Wilayah Kerja Puskesmas Kaliwates Kabupaten Jember (Januari, 2019; n= 84).

\begin{tabular}{lcc}
\hline Variabel & Mean & $S D$ \\
\hline Perilaku Perawatan Diri & 2,27 & 0,45 \\
\hline
\end{tabular}

Berdasarkan tabel 7 didapatkan bahwa hasil nilai rata - rata variabel perilaku perawatan diri adalah 2,27 hari dalam seminggu dengan standar deviasi 0,45 hari. 
Tabel 8. Nilai Rerata Indikator Perilaku Perawatan Diri pada Klien DM Tipe 2 di Wilayah Kerja Puskesmas Kaliwates Kabupaten Jember (Januari, 2019; $n=84$ ).

\begin{tabular}{lcc}
\hline Variabel & Mean & SD \\
\hline Diet & 4,47 & 0,65 \\
Olahraga/Aktivitas Fisik & 1,92 & 1,95 \\
Pemeriksaan Kadar Gula & 0,71 & 0,65 \\
Darah & & \\
Manajemen Obat & 5,26 & 2,96 \\
Perawatan Kaki & 0,12 & 0,65 \\
\hline
\end{tabular}

Tabel 8 menunjukkan bahwa setiap nilai rata - rata indikator perilaku perawatan diri klien DM tipe 2 di wilayah kerja Puskesmas Kaliwates nilai pertama tertinggi adalah manajemen obat dengan nilai 5,26 hari dalam seminggu selanjutnya di ikuti dengan diet atau pengaturan pola makan dengan nilai rata - rata 4,47 hari dalam seminggu. Sedangkan, untuk nilai rata rata terendah yaitu pada perawatan kaki dengan nilai 0,12 hari dalam seminggu.

\section{Hubungan Dukungan Sosial Keluarga dengan Perilaku Perawatan Diri.}

Tabel 9. Hasil Analisis Hubungan Dukungan Sosial Keluarga dengan Perilaku Perawatan Diri pada Klien DM Tipe 2 di Wilayah Kerja Puskesmas Kaliwates Kabupaten Jember ( Januari, 2019; $n=84$ )

\begin{tabular}{llc}
\hline Variabel & \multicolumn{2}{c}{ Perilaku Perawatan Diri } \\
\hline Dukungan & $\mathrm{R}$ & 0,378 \\
Sosial & $\rho$ Value & 0,001 \\
Keluarga & Arah & $+($ Positif $)$ \\
& Korelasi & \\
\hline
\end{tabular}

Tabel 9 menunjukkan hasil analisis data untuk mengetahui adanya korelasi antara dukungan sosial keluarga dengan perilaku perawatan diri menggunakan uji statistik spearmen rank dan didapatkan hasil $p$ value $=$ 0,001 yang berarti bahwa $\mathrm{Ha}$ diterima. Hal ini menunjukkan bahwa terdapat hubungan antara dukungan sosial keluarga dengan perilaku perawatan diri. Nilai korelasi antara dua variabel tersebut sebesar 0,378 yang menunjukkan bahwa kekuatan hubungan lemah. Nilai korelasi positif, hal ini berarti semakin tinggi dukungan sosial keluarga maka akan semakin tinggi pula perilaku perawatan diri klien DM tipe 2.

\section{Pembahasan}

\section{Karakteristik Responden}

Hasil penelitian yang dilakukan di Wilayah Kerja Puskesmas Kaliwates Kabupaten Jember pada 84 responden menunjukkan rata - rata usia klien DM tipe 2 yaitu berusia 57,64 tahun. Berdasarkan hasil penelitian tersebut sejalan dengan konsep DM tipe 2 dimana usia lebih dari 45 tahun fungsi fisiologis dari manusia mengalami penurunan dengan cepat yang akan mempengaruhi fungsi dari sistem endokrin pancreas dalam memproduksi insulin [14].

Lebih dari separuh klien DM tipe 2 yaitu berjenis kelamin perempuan dibandingkan dengan laki - laki dengan jumlah 50 orang (59\%). Hasil penelitian tersebut sebanding dengan data statistik Riskesdas pada tahun 2013 menunjukkan bahwa prevalensi DM lebih banyak terjadi pada perempuan dibandingkan dengan laki - laki. Prevalensi DM lebih tinggi terjadi pada perempuan dikarenakan pada prempuan secara fisik memiliki peluang peningkatan indeks masa tubuh (IMT) yang lebih besar sehingga perempuan lebih beresiko mengalami obesitas (kegemukan). [15].

Tingkat pendidikan responden yang paling banyak adalah SMA sebanyak 29 orang (34,5\%). Seseorang yang memiliki pendidikan lebih tinggi biasanya memiliki tingkat pengetahuan yang lebih baik tentang kesehatan sehingga memiliki kesadaran untuk menjaga kesehatannya [16]. Namun, peneliti berpendapat bahwa pendidikan yang tinggi belum tentu membuat seseorang lebih peduli terhadap kesehatannya. Pada kenyataan di lapangan yang terjadi masih banyak orang orang yang berpendidikan tinggi mengabaikan kesehatannya dikarenakan sibuk dengan berbagai alasan. Dengan kesibukannya terkadang orang lupa terhadap pola hidup khususnya dalam pola makan, lebih memilih makanan yang cepat saji. Sehingga dari keadaan tersebut dapat meningkatkan resiko terjadinya DM tipe 2.

Jenis pekerjaan yang paling banyak yaitu ibu rumah tangga dengan jumlah 26 orang (31\%). Sebagian besar ibu rumah tangga beresiko tinggi untuk menderita DM dikarenakan selain dari pekerjaan rumah tangga, ibu rumah tangga tidak pernah melakukan aktifitas fisik lain setiap harinya [17].

Rata rata lama klien menderita DM tipe 2 di adalah selama 6 tahun. Klien yang hidup dengan diabetes lebih dari 10 tahun memiliki praktik perawatan diri yang baik [18]. Hasil penelitian di wilayah kerja Puskesmas Kaliwates dapat dikatakan jika rerata lama menderita DM selama 6 tahun masih tergolong sebentar dari pada lama terdiagnosa lebih dari 10 tahun sehingga perilaku perawatan diri klien DM tipe 2 belum dilakukan secara optimal.

\section{Dukungan Sosial Keluarga}

Hasil penelitian yang dilakukan di wilayah kerja puskesmas kaliwates didapatkan nilai median 
responden pada variabel dukungan sosial keluarga adalah 86 dengan nilai minimal 69 dan maksimal 106. Tingkat dukungan sosial keluarga pada penelitian ini, paling banyak berada pada dukungan sosial keluarga baik dengan jumlah 82 orang $(97,6 \%)$ dan hanya 2 orang $(2,4 \%)$ yang memiliki dukungan sosial keluarga buruk.

Hasil tersebut didukung oleh penelitian lainnya dimana menjelaskan bahwa nilai median dukungan sosial keluarga klien DM tipe 2 adalah 86,4 [19]. Penelitian serupa klien DM tipe 2 di makasar di dapatkan hasil bahwa responden terbanyak mendapat dukungan sosial keluarga baik dengan jumlah 21 orang dari 22 responden $(95,45 \%)$ dan hanya 1orang $(4,55 \%)$ yang memiliki dukungan sosial keluarga buruk [20].

Indikator tertinggi yaitu pada dukungan emosional dimana hasil yang diperoleh yaitu rata - rata nya dengan nilai 3,20. Hasil tersebut menunjukkan bahwa rata - rata responden sering menerima dukungan emosional dari keluarga. Dukungan emosional yang diberikan oleh keluarga berisikan tentang bagaimana keluarga mengerti masalah dan mendengarkan keluhan klien bercerita tentang diabetes yang dialami, memberikan kenyamanan dalam memahami jika klien sedih dengan diabetes, serta keluarga mengerti untuk membantu dalam mengatasi diabetes nya. Dukungan emosional yang diberikan oleh keluarga dapat memberikan kenyamanan dan dorongan ketika klien DM tipe 2 menghadapi frustasi atau kesusahan selama perawatan diabetes [21].

Indikator terendah dari variabel dukungan sosial keluarga yaitu dukungan informasi dengan nilai rata - rata 2,53 yang artinya klien DM tipe 2 jarang mendapatkan dukungan informasi dari keluarga. Dukungan informasi yang rendah dikarenakan masih banyak dari keluarga yang masih belum paham mengenai penyakit DM secara mendasar. Selain itu, dukungan informasi rendah juga dikarenakan kurang nya motivasi keluarga untuk mengikuti kegiatan penyuluhan di masyarakat terkait DM yang dilakukan oleh puskesmas Kaliwates melalui kegiatan posbindu yang melibatkan peran serta kader kesehatan yang seharusnya dapat meningkatkan pengetahuan keluarga dalam memberikan informasi terkait penyakit DM pada klien DM.

\section{Perilaku Perawatan Diri}

Hasil penelitian yang dilakukan di wilayah kerja puskesmas kaliwates menunjukkan bahwa rata - rata nilai perilaku perawatan diri klien DM tipe 2 adalah 2,27 hari dalam seminggu. Hal tersebut menunjukkan bahwa perilaku perawatan

e-Journal Pustaka Kesehatan, vol. 7 (no. 2), Mei 2019 diri belum dilakukan secara optimal, dikarenakan belum dilakukan secara rutin dalam 7 hari.

Indikator terendah variabel perawatan diri dalam hasil penelitian ini adalah perawatan kaki dengan nilai rata - rata 0,12 hari. Hal ini memiliki arti bahwa dalam seminggu klien DM tipe 2 tidak pernah melakukan perawatan kaki. Hambatan dari klien DM jarang melakukan perawatan kaki dikarenakan munculnya rasa malas, dan tidak patuh dalam melakukan perawatan kaki karena harus menggunakan kaos kaki dan sandal atau sepatu yang sesuai. Faktor lain yang dapat mempengaruhi perawatan kaki ialah kondisi lingkungan disekitar tempat tinggal responden.

Indikator tertinggi perawatan diri yaitu manajemen konsumsi obat dengan rata rata 5,26 hari yang artinya responden mengkonsumi obat selama 5 hari dalam seminggu. Klien yang memiliki kepercayaan mengenai bentuk dari penyakitnya memiliki pengaruh yang besar terhadap keinginan mereka untuk mengikuti saran kesehatan dalam melakukan terapi pengobatan [22]. Kepatuhan dalam minum obat yang terjadi pada klien DM tipe 2 dikarenakan mereka mempunyai kesadaran dan memiliki pemahaman yang baik tentang pentingnya mengkonsumsi obat $\mathrm{OHO}$, supaya kadar glukosa darah tetap dalam rentang normal [23].

\section{Hubungan Dukungan Sosial Keluarga dengan Perilaku Perawatan Diri pada Klien Diabetes Melitus Tipe 2}

Hasil uji statistik dalam penelitian ini menunjukkan bahwa terdapat hubungan antara dukungan sosial keluarga dengan perilaku perawatan diri klien DM tipe 2 di wilayah kerja Puskesmas Kaliwates Kabupaten Jember. Hasil tersebut dibuktikan dengan nilai $p$ value $=0,001$. Dukungan sosial keluarga dan perilaku perawatan diri memiliki hubungan yang signifikan dengan tingkat kekuatan yang lemah. Nilai korelasi bersifat positif yang berarti semakin tinggi dukungan sosial keluarga semakin tinggi pula perilaku perawatan diri pada klien DM tipe 2.

Dukungan sosial keluarga merupakan sumber dalam perubahan perilaku kesehatan mengenai perawatan diri diabetes. Diantara masyarakat, keluarga merupakan salah satu anggota yang dapat memberikan dukungan sosial untuk perawatan diri klien DM tipe 2 [24,25]. Hal ini sejalan dengan penelitian lain yang menyatakan bahwa salah satu manajemen penyakit DM yaitu perawatan diri, dalam perawatan diri klien DM tipe 2 juga diperlukan dukungan dari keluarga secara positif sehingga dapat mempengaruhi outcome yang baik [26]. Dukungan sosial keluarga mempunyai hubungan yang signifikan dengan perilaku perawatan diri pada klien DM tipe 2, 
dengan adanya intervensi yang fokus pada peningkatan dukungan sosial dari keluarga dan perawatan diri dalam mengontrol diabetes nya akan lebih efektif dalam meningkatkan kontrol glikemik [27].

\section{Simpulan dan Saran}

Terdapat hubungan yang signifikan antara dukungan sosial keluarga dengan perilaku perawatan diri klien DM tipe 2 di wilayah kerja Puskesmas Kaliwates Kabupaten Jember. Nilai korelasi bersifat positif yang berarti semakin tinggi dukungan sosial keluarga maka semakin tinggi perawatan diri klien DM tipe 2. Hubungan dari ke dua variabel bersifat lemah.

Perawat perlu dalam melakukan intervensi tidak hanya fokus pada klien DM tipe 2, melainkan juga memberikan edukasi kepada keluarga bahwa dukungan sosial keluarga sangat mempengaruhi perawatan diri dari klien DM tipe 2. sehingga dapat memberikan intervensi guna mempertahankan perawatan diri klien melalui dukungan sosial keluarga.

\section{Daftar Pustaka}

[1] World Health Organization. Global report on diabetes. [Intenet]. World Health Organization; 2016 [cited 18 September 2018]. Available from: http://apps.who.int/iris/bitstream/handle/106 65/204871/9789241565257_eng.pdf

[2] International Diabetes Federation. Diabetes atlas [Internet]. America : International Diabetes Federation; 2017 [cited 10 September 2018]. Available from: http://www.diabetesatlas.org/

[3] International Diabetes Federation. Diabetes atlas [Internet]. America : International Diabetes Federation; 2017 [cited 10 September 2018]. Available from: http://www.diabetesatlas.org/

[4] Badan Penelitian dan Pengembangan. Riset kesehatan dasar (riskesdas) [Internet]. 2013 [cited 15 September 2018] 1(384). Available from: http://www.depkes.go.id/resources/downloa d/general/Hasil\%20Riskesdas\%202013.pdf

[5] Jember. Laporan Kunjungan (Ibi) Kabupaten Jember tahun 2015. Jember : Dinas Kesehatan Kabupaten Jember; 2017.

[6] Sutandi A. Manajemen self management education sebagai metode alternatif dalam perawatan mandiri pasien diabetes melitus di dalam keluarga [Internet]. 2012 [cited 18 Juli 2018]; 29 (321). Available from: https://ejournal.jurwidyakop3.com/index.ph

e-Journal Pustaka Kesehatan, vol. 7 (no. 2), Mei 2019 p/majalah-ilmiah/article/view/64/61

[7] International Diabetes Federation. Diabetes atlas [Internet]. America : International Diabetes Federation; 2015 [cited 10 September 2018]. Available from: http://www.diabetesatlas.org/

[8] Kusniawati. Analisis faktor yang berkonstribusi terhadap self care diabetes pada klien diabetes melitus tipe 2 di rumah sakit umum tangerang. Tesis. Depok: Fakultas IImu Keperawatan Program Magister Keperawatan Universitas Indonesia; 2011.

[9] Sonsona JB. Factors influencing diabetes self-management of filipino americans with type 2 diabetes mellitus: a holistic approach. Dissertations. Walden University; 2014.

[10] American Diabetes Association. Standards of medical care in diabetes. The Journal of Clinical and Applied Research and Education. [Internet]. America; 2015. [cited 15 September 2018]. Available from: http://www.bvs.hn/Honduras/UICFCM/Diabet es/Diabetes.Care-1.pdf

[11] Naderimagham. Development and psychometric properties of a new social support scale for self-care in middle-aged patients with type II diabetes. BMC Publich Health [Internet]. 2012 [cited 19 September 2018]; 12(10). Available from: https://bmcpublichealth.biomedcentral.com/tr ack/pdf/10.1186/1471-2458-12-1035

[12] Yusra, A. Hubungan antara dukungan keluarga dengan kualitas hidup pasien diabetes melitus tipe 2 di poliklinik penyakit dalam rumah sakit umum pusat fatmawati jakarta. Tesis. Depok: Fakultas IImu Keperawatan Program Magister Keperawatan Universitas Indonesia; 2011.

[13] Tamara E, Bayhakki, \& Nauli FA. Hubungan antara dukungan keluarga dan kualitas hidup pasien diabetes mellitus tipe 2 di rsud arifin achmad provinsi riau. JOM [Internet]. 2016 [cited 15 Juni 2018];(2):[pp1-7]. Available from:https://jom.unri.ac.id/index.php/JOMPSI K/article/view/3433/3329

[14] National Institute of Diabetes and Digestive and Kidney Diseases. Risk factors for type 2 diabetes [Internet]. National Institute of Diabetes and Digestive and Kidney Diseases; 2016 [20 September 2018]. Available from: https://www.niddk.nih.gov/healthinformation/d iabetes/overview/risk-factors-type-2-diabetes

[15] Irawan D. Prevalensi dan faktor - faktor risiko kejadian diabetes melitus tipe 2 di daerah urban indonesia (analisis data sekunder riskesdas 2007). Tesis. Fakultas Kesehatan 
Masyarakat. Universitas Indonesia; 2010.

[16] Irawan D. Prevalensi dan faktor - faktor risiko kejadian diabetes melitus tipe 2 di daerah urban indonesia (analisis data sekunder riskesdas 2007). Tesis. Fakultas Kesehatan Masyarakat. Universitas Indonesia; 2010.

[17] Patil RS, \& Gothankar JS. Assessment of risk of type 2 diabetes using the indian diabetes risk score in an urban slum of pune, maharashtra, india: a cross-sectional study. Journal of Publich Health. [Internet]. 2016 April [cited 25 Januari 2019]; 5 (1). Available from: http://www.whoseajph.org/temp/WHOSouthEastAsiaJPubli cHealth51531262609 033026.pdf

[18] Gurmu Y, Gela D, \& Aga F. Factors associated with self-care practice among adult diabetes patients in west shoa zone, oromia regional state, ethiopia. BMC Health Srvice Research [Internet]. 2018 [cited 10 September 2018]; 4 (11). Available from: https://www.ncbi.nlm.nih.go v/pmc/articles/PMC6154910

[19] Ramadhani DY, Agusman F, \& Hadi R. Karakteristik dukungan keluarga dan efikasi diri pada lanjut usia diabetes melitus tipe 2 di kelurahan padangsari semarang. Jurnal Ners Lentera [Internet]. 2016 [cited 25 Januari 2019]; 4 (2). Available from: https://media.neliti.com/media/publications/ 231996-karakteristik-dukungankeluargadan-efik-9780ef88.pdf

[20] Buraena S, As'ad S, Aman AM, Nurdin AA, \& Ramadany $S$. The effect of education against glycemic control in type 2 diabetes mellitus: studies of family support and compliance treatment supervision. International journal of sciences: basic and applied eesearch [Internet]. 2016 [cited 24 Januari 2019]; 29 (03). Available from: https://pdfs.semanticscholar.org/9fd7/4728 ca264a2be8e2d4158e0c07e7d3880f66.pdf
[21] Baig AA, Benitez A, Quinn MT, \& Burnet DL. Family interventions to improve diabetes outcomes for adults. HHS Public access [Internet]. 2015 [cited 24 Januari 2019]; 1353 (1). Available from: https://www.ncbi.nlm.nih.gov/pmc/articles/PM C4624026/pdf/ nihms 701902.pdf

22] Home R. Pharmacy practice. School of pharmacy, University London, London UK; 2005.

[23] Kusniawati. Analisis faktor yang berkonstribusi terhadap self care diabetes pada klien diabetes melitus tipe 2 di rumah sakit umum tangerang. Tesis. Depok: Fakultas IImu Keperawatan Program Magister Keperawatan Universitas Indonesia; 2011.

[24] Fisher L, Chesla CA, \& Bartz RJ. The family and type 2 diabetes : a framework for intervention. The diabetes educator. [Internet]. 1998 [cited 20 Januari 2019]; 24 (5). Available from: https://www.ncbi.nlm.nih. gov/pubmed/9830956

[25] Tang TS, Brown MB, Funnell MM, Anderson MT. Social support, quality of life, and selfcare behaviors among african americans with type 2 diabetes. The diabetes educator [Internet]. 2008 [cited 20 Januari 2019]; 34 (2). Available from: https://www.ncbi.nlm.nih. gov/pubmed/18375776

[26] Baig AA, Benitez A, Quinn MT, \& Burnet DL. Family interventions to improve diabetes outcomes for adults. HHS Public access [Internet]. 2015 [cited 24 Januari 2019]; 1353 (1). Available from: https://www.ncbi.nlm. nih.gov/pmc/articles/PMC4624026/pdf/ nihms 701902.pdf

[27] Mohebi S, Parham M, Sharifirad G, Gharlipour Z, Mohammadbeigi A, Rajati F. Relationship between perceived social support and self-care behavior in type 2 diabetics: A cross sectional study. Journal of Education and Health Promotion [Internet] 2019 [cited 26 Januari 2019]; 7. Available from:https://www.ncbi.nlm.nih.Gov/pmc/articl es/PMC5903155/ 